\title{
The Role of Universities in Inter-organizational Knowledge Collaborations
}

\author{
Ardalan Haghighi Talab ${ }^{1}$ - Victor Scholten ${ }^{1}$. \\ Cees van Beers ${ }^{1}$
}

Received: 7 September 2016 / Accepted: 6 June 2018/Published online: 27 June 2018

(C) The Author(s) 2018

\begin{abstract}
Organizations collaborate with external actors in order to acquire knowledge resources they cannot develop internally for economic and/or technical reasons. Mode 2 and Triple Helix models have examined the role of different organizational types in collaborative creation and knowledge use. This paper is an empirical investigation on whether universities differ from business-oriented or industrial organization types with regard to the extent of their knowledge collaborations. Using SEM methodology, it demonstrates the role of universities in knowledge collaboration through a survey of 472 organizations in the 7th Framework Programme for Research and Technological Development of the European Commission, Energy theme (FP7-Energy). In line with the Triple Helix model, universities are found to exhibit more extensive knowledge collaboration than businesses. Also, between-university collaborations are found to be more extensive knowledge collaboration relationship types than between-business relationships. The findings imply that (1) publically funded consortia should be aware that universities are more conducive and hence more effective in inter-organizational knowledge collaboration networks than other organizational types, particularly compared to for-profit business organizations. Universities should be included in these consortia. (2) Business organizations that do not have an extensive relationship with universities need to reconsider their partner portfolio and extend the knowledge collaboration of their network by connecting to more universities.(3) Policymakers should not only involve academic organizations but also include groups of more than one university per consortium to enable between-university knowledge collaboration to boost collaborative knowledge exploration and exploitation of the consortia.
\end{abstract}

Ardalan Haghighi Talab

info@euenergyexport.com

1 Technology, Policy, and Management, Delft University of Technology, Jaffalaan 5, 2628 BX Delft, The Netherlands 
Keywords Inter-organizational $\cdot$ Knowledge collaboration · Triple Helix · University

\section{Introduction}

In the last two decades, the output performance of organizations has increasingly been dominated by the production factor knowledge. Due to the increasing complexity of technology and markets, organizations cannot develop all required knowledge internally and therefore aim to collaborate with external actors. In particular, knowledge collaboration between universities and businesses has received considerable attention. Since the 1990s, the mainstream understanding of knowledge collaboration has shifted from a linear process (frequently termed as "Mode 1" or ivory tower) towards an iterative inter-organizational collaboration process. Researchers such as Gibbons et al. (1994) and Leydesdorff and Etzkowitz (1998) have proposed two knowledge collaboration models that explain the role of different organizational types in the collaborative production and utilization of knowledge. These are the Mode 2 and Triple Helix models respectively.

In Mode 2, knowledge production focuses solely on applicability. It is contextdriven and problem focused. Universities play a subordinate role in innovation systems compared to business firms, and are hence said to be on the "demise" path. Gibbons et al. (1994) contested the ivory tower knowledge production for linear innovation processes and concluded that production of new knowledge takes place outside the loci and disciplines of universities. In the Triple Helix model ${ }^{1}$ (THm) (Leydesdorff and Etzkowitz 1998), knowledge production focuses on the simultaneous interaction of theoretical, practical, and legislative knowledge of several organizational types. The university in THm plays the role of a "salient" actor that is central in innovation systems.

These opposing views call for evidence to further identify the role of universities in knowledge development through collaboration. Should universities be allocated more or fewer collaboration opportunities? Should collaboration consortia involving more universities be valued more or valued less? This paper explores the differences of the two models and empirically investigates their relevance to identify the role of universities in the context of the European Framework Programmes.

The role of universities in knowledge production and innovation systems (Edquist 2010) has been studied in the context of public-private research partnerships (Stiglitz and Wallsten 1999), agents of national economic competitiveness (Greenaway and Haynes 2000), patenting and licensing agents (Nelson 2001), and entrepreneurial academe (Mavi 2014) and led to different views on the relevance of universities in knowledge production and utilization. These different views are mainly based on conceptual debates rather than empirical investigations. They impose profound political implications (see, e.g., Carayannis and Campbell 2011; Schoonmaker and Carayannis 2013) on the role of universities in knowledge collaboration networks. "Generally, scientists are oriented towards the reputation-based reward system of open science, while industry scientists face the commercial imperative to produce exploitable results"

\footnotetext{
${ }^{1}$ Other research extended this model to four and five helices (Carayannis and Campbell 2011; Carayannis et al. 2012).
} 
(Perkman and Walsh, 2007 p.273). Consequently, the authors called for further empirical research on whether knowledge collaboration is affected by organizational types. Furthermore, considerable research has been conducted on knowledge collaboration in business alliances, B\&B, (Hagedoorn et al. 2000) and in university-industry alliances, U\&B, (Florida and Cohen 1999). However, little attention has focused on university and university (U\&U) knowledge collaboration relationships. This can be attributed to the financial and strategic aspects of these types of inter-organizational relationships. $\mathrm{U} \& \mathrm{~B}$ and $\mathrm{B} \& \mathrm{~B}$ relationships are perceived as more financially substantive compared to $\mathrm{U} \& \mathrm{U}$ relationships. $\mathrm{U} \& \mathrm{~B}$ and $\mathrm{B} \& \mathrm{~B}$ knowledge collaborations are also perceived to be strategically more critical than $U \& U$ relationships, due to the possible unintended spillover of strategic knowledge (e.g., trade secrets) to competitors. Examples of U\&U collaboration include co-authorship, co-patenting, academic mobility, collaborative teaching (e.g., transnational student exchange programs), and transnational support for innovation and technology transfer (e.g., international incubation). U\&U collaboration also occurs in development programs by national, regional, or supranational authorities (Stiglitz and Wallsten 1999), for example, the Framework Programmes (FPs) for Research and Technological Development of the European Union (Caloghirou et al. 2001). Although there is ample literature on organizational learning and knowledge management, the nature of knowledge collaboration behavior between universities remains mostly unexplored and poorly understood (Bock et al. 2005; Milne 2007).

We argue that various organizational-level factors have an effect on knowledge collaboration and that these depend on organizational type, e.g., university, business, and government. Therefore, organizational type may explain variations in the extent of inter-organizational knowledge collaboration. Our main research question is: do universities differ from business-oriented ${ }^{2}$ organization types in the extent of their knowledge collaboration? We measure the extent of knowledge collaboration by its manifestations: (1) extent of involvement in group discussions; (2) extent of development of new ideas/skills due to collaboration; and (3) extent of learning to exchange ideas/skills (adopted from Davenport and Prusak 1998 and Muthusamy and White 2005). The empirical examination of the two competing models assists evidence-based decisionmaking by all organization types: universities and businesses in partner selection, consortia in formation decisions, and governmental organizations in the resource allocation and division of labor. We aim to answer the research question at two levels:

1. At an organizational level, do universities have more extensive knowledge collaboration than business organizations?

2. At an inter-organizational level, does a university and university relationship type have more extensive inter-organizational knowledge collaboration than a business and business relationship type?

The next section describes the theoretical framework of inter-organizational knowledge collaboration. We examine the differences in organizational logic of a university versus a business-oriented organization and formulate our hypotheses. In the "Method"

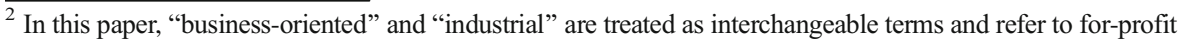
firms.
} 
section, we describe our method, data source, and operationalization. The "Results" section reports the empirical results. The "Limitations and Implications" section concludes.

\section{Knowledge Collaboration}

\section{Terminology and Rationale}

Knowledge sharing between personnel is a key dimension of learning organizations and can contribute to organizational learning and innovation (Brown and Duguid 2001; Cohen and Levinthal 1990; Goh 1998). Previous research suggests a positive relationship between intra-organizational knowledge sharing and organizational performance (e.g., Harlow 2008; Srholec 2014). Furthermore, knowledge exploration and exploitation can also take place at the overlap of many different kinds of organizations (e.g., businesses, universities, research institutes, and governments) giving knowledge-based activities an inter-organizational dimension. To make inter-organizational knowledge collaboration possible, concepts of knowledge transfer (i.e., from sender to receiver), knowledge exchange (i.e., from sender to receiver and reciprocated), and knowledge sharing (from sender to multiple receivers) need to be combined into knowledge collaboration.

Inter-organizational knowledge collaboration networks are defined as formally established arrangements spanning different organizations aimed at pooling knowledge resources for new knowledge exploration and/or exploitation (Alter and Hage 1993; Freeman 1991; Powell and Grodal 2005). Alliances with other organizations are often recommended to acquire new knowledge, skills, and expertise to enhance the performance of organizations (Hamel 1991). Knowledge collaboration is considered to reduce the costs of attaining knowledge through risk sharing. It also reduces the cost of recognizing and solving problems, i.e., exploration (Sher and Lee 2004), and increases the knowledge utilization capacity of organizations. "Knowledge facilitates the use of other knowledge" (Powell et al. 1996, p.120). Existing, i.e., already explored, knowledge can potentially be utilized in new areas via inter-organizational knowledge collaboration, i.e., exploitation. The more heads and hands involved, the more knowledge exploration and exploitation capacity.

\section{Theory and Hypotheses}

Florida and Cohen (1999) argue that a key role for universities in the knowledge economy is to be a "collector of talent." Universities educate, develop, and produce talent and consequently contribute to the quality of knowledge infrastructure in a country or a region. In a knowledge-based economy, universities constitute a key element of the national or regional innovation system, not only as a human capital provider/developer but also as a seed-bed of new firms (Etzkowitz et al. 2000). However, Gibbons et al. (1994, p.76) assert that "the tradition of university-based research is threatened by the encroachment of industry and profit-making mentality and values."

Variations in the extent of the knowledge collaboration based on organizational type can be estimated to reflect on the role of the universities in inter-organizational 
collaborations. However, heterogeneity in the extent of knowledge collaboration can also be attributed to variations in knowledge collaboration antecedents such as motivation, opportunity, and ability (MOA) (Argote et al. 2003). The MOA framework, originally developed at the individual level, is also known to be effective in explaining behavior at the organizational level (Clark et al. 2005). We use the MOA framework to disentangle the output variation due to organizational type and/or the MOA factors. By extracting the MOA impact, we can estimate the exact effects of organizational types.

\section{Motivation, Opportunity, and Ability Framework}

Three major theories are available to understand collaborative behavior: (1) the theory of reasoned action (TRA) (Fishbein 1967), and its improved version, the theory of planned behavior (TPB) (Ajzen and Fishbein 1970), (2) the cognitive-affective processing system (CAPS) (Mischel and Shoda 1995), and (3) the motivation, opportunity, and ability framework (MOA) (Argote et al. 2003; Blumberg and Pringle 1982).

Knowledge collaboration is a behavior that can happen intra-organizationally at an individual level or inter-organizationally at an organizational level. The TRA, the improved version TPB, and the CAPS models focus on individual-level mechanisms that shape behavior. These include attitudes, beliefs, subjective norms, perceived controls, affective responses, emotions, feelings, and other effects accompanying psychological reactions. As these mechanisms exclusively address the individual level, we do not use them for our organizational-level study of inter-organizational knowledge collaboration. The MOA framework constitutes a set of broad and distinct categories of variables (Argote et al. 2003; Kelloway and Barling 2000) that also have organizational-level conception (Clark et al. 2005). In MOA, motivation is the willingness to conduct behavior, i.e., knowledge collaboration behavior. Ability represents the skills, capabilities, and capacities related to the behavior. Opportunity embodies all the situational mechanisms that enable or hamper behavior.

\section{Differences of University and Business Relationships: Knowledge, a Public, or a Private Good}

Inter-organizational knowledge collaboration is more challenging than intraorganizational collaborations especially when the collaborating organizations pursue different and often opposing organizational rules and agendas. A number of factors can shed some light on this statement.

Knowledge, although occasionally subject to temporary monopolization or secrecy, is essentially a public good. A public good is a shared resource from which every group member can benefit regardless of their contribution to its provision. No one can be prevented from benefiting from knowledge once it has been provided; i.e., nonexclusivity. Moreover, the availability of knowledge resources does not diminish with usage (Olson 1965). Knowledge can be used simultaneously by many without diminishing its availability to any of the users, and it will not become depleted by usage (Foray 2004), i.e., non-rivalry. Adding established knowledge of one field/ domain to a new field/domain enriches the existing knowledge base of both fields/ domains, i.e., cumulativeness. Combining and re-utilizing knowledge in new contexts adds value to the original knowledge resource through validation and extension of its 
application scope. New knowledge solves problems of the recipient field/domain by extending its knowledge base. To conclude, knowledge is a non-excludable, non-rival, and cumulative resource that generates increasing returns through its systematic exploration and exploitation.

Some organizational types prefer knowledge to be privatized as "proprietary knowledge" to be able to reap its benefits. Others publicize knowledge to gain the acknowledgement for both "serving the public" and "priority of discovery." "What makes a knowledge-worker a 'technologist' rather than a 'scientist', in this usage, is not the particular cognitive skills or the content of his or her expertise [...] what matters is the socio-economic rule structures under which the research takes place." (Partha and David 1994, p.495) Depending on the socio-economic rules of organizations, knowledge can either be circulated as a public good or alternatively safeguarded as a private good.

Universities have institutional rules to spread knowledge as a part of their public mission (Partha and David 1994; Stern 2004). The university system is rooted in Mertonian norms of science (Merton 1973). Universities perform based on collegiate reputation-based institutional rules. For the academic system to work, publication or presentation of knowledge is crucial to trigger reputation building via disseminating as much knowledge as possible and to gain the priority of discovery. Mertonian "communality" asserts complete and free disclosure (see Partha and David 1994 for detailed dynamics of knowledge sharing of scientists and technologists).

\section{Hypotheses}

The Mode 2 outlines the end of the universities' monopoly in knowledge exploration. The conclusion of Mode 2 model follows as: "universities, in particular, will comprise only a part, perhaps only a small part, of the knowledge producing sector." (Gibbons et al. 1994, p.85). Although the linear innovation models (taking an ivory tower monopolistic role for universities) are correctly dismissed in Mode 2, the resultant conclusion does not directly follow from the premises of wider knowledge exploration loci and disciplines. Universities may still comprise the crucial organizational type in inter-organizational knowledge collaborations and may still play a salient role in knowledge production. Indeed, universities in THm are viewed as important actors in the networks of knowledge-based activities (Cooke et al. 2004; Etzkowitz 1998). The THm pictures universities as "entrepreneurial" or "generative" institutions (Etzkowitz and Leydesdorff 2000; Etzkowitz and Zhou 2006; Gunasekara 2006). As scientific knowledge is important for innovation and new business development (Mansfield and Lee 1996), universities have a more prominent role as actors in regional and national economic development. Accordingly, exploitation of university-generated knowledge has a stronger role in government policies (Lambert 2003). Universities have a direct role in society by commercializing research results, i.e., "entrepreneurial science" and "third mission" (Etzkowitz 1998; Martin 2003). Considering the extent of "engagement in discussions," "development of ideas or skills," and "learning due to collaboration" as manifestations of the extent of interorganizational knowledge collaboration, we propose the following hypothesis:

Hypothesis 1: Universities collaborate more extensively in inter-organizational knowledge networks than business organizational types. 
In business organizations, sharing valuable knowledge and admitting to require knowledge may be perceived as risky (Borgatti and Cross 2003). From an economic perspective, the cost to individuals may be in the effort and time spent in sharing knowledge. However, by sharing knowledge, businesses may help advance competitors at the cost of diminishing their own chances. Firms hesitate to enhance their rivals' knowledge base as long as this knowledge hoarding is not costly to their own knowledge base. Their primary concern is the appropriation of knowledge for creating a sustained competitive position which contributes to shareholder value. Openness to external actors is only used as a strategic mechanism to gain advantage (Chesbrough 2006). The business-oriented knowledge creating entities (e.g., commercial R\&D) aim at extracting rent from their available knowledge and keep their knowledge as a proprietary commodity.

While universities in general aim to make knowledge as public as possible, businesses generally aim to keep their knowledge as private as possible. Even though universities occasionally patent or businesses sometimes provide open access, the two worlds of university and business have clear boundaries on their institutional rules and agendas that govern knowledge. These boundaries are the main obstacle to inter-organizational knowledge collaboration (Partha and David 1994). Universities make knowledge "leaky" so that they become acknowledged as pioneering discoverers, whereas businesses make knowledge "sticky" so that they can control a resource that is not available to their competitors (Brown and Duguid 2001). These leads to hypothesis 2.

\section{Hypothesis 2: Knowledge collaboration between universities (U\&U relationships) is more extensive than knowledge collaboration between businesses ( $B \& B$ relationships)}

\section{Controlling the Confounding Effects}

In the empirical part of this study, we use a multivariate regression analysis that relates inter-organizational knowledge collaboration to the organizational types, the MOA framework, and a number of control variables. First, we explain the context of the knowledge collaborations used in this study.

Inter-organizational knowledge collaborations in this study take place in the project consortia in the European Union 7th Framework Programme for Research and Technological Development Energy theme (FP7-Energy). FP7-Energy constitutes project consortia each comprising numerous types of organizations: universities, businesses, research institutes, and administrative organizations. The main project variables include the duration of the collaborative project, the geographical distance between the collaborators, and the availability of information technology (IT) to the members of the project consortium.

In project-based inter-organizational knowledge collaborations, the allocated workload of the project is assumed to be proportional to the project's duration. A longer project means that more tasks need to be coordinated and performed, which might distract the collaborators from focusing on an extensive collaboration. Longer projects are also less likely to give the collaborators a sense of urgency that shorter projects do. Project duration is expected to negatively affect the extent of knowledge collaboration. 
Geographical proximity and colocation are beneficial because such proximity increases the likelihood of communication between actors (Zahn 1991) and facilitates knowledge spillovers (e.g., Almeida and Kogut 1999; Malmberg and Maskell 2002). Geographical proximity entails that working close to the potential source of knowledge increases the probability and the extent of learning from that source. Borgatti and Cross (2003) have shown that the likelihood of having effective and efficient knowledge flows decreases as distance increases. Empirical studies on university spillovers have found that knowledge spillovers from universities are localized and contribute to higher rates of corporate patents or innovations in geographically bound areas (e.g., Anselin et al. 1997; Feldman and Florida 1994; Fischer and Varga 2003; Van Der Panne and Kleinknecht 2005). Knowledge spillovers are "confined largely to the region in which the research takes place" (Hewitt-Dundas 2013, p.94). Geographical distanceis expected to negatively affect the extent of knowledge collaboration.

Utilizing information technology systems in knowledge collaborations can support organizations. IT removes communication barriers and offers access to even geographically distant collaborators. The availability of IT is expected to positively affect the extent of knowledge collaboration.

In summary, the literature review is represented by a conceptual framework of knowledge collaboration of different organizational types. The conceptual framework has the extent of inter-organizational knowledge collaboration which is dependent on the MOA concepts - comprising motivation, opportunity, and ability - the organization types, and the control variables. The MOA concepts are used to represent the possible variation due to organizational-level differences, whereas organizational type reflects the type of organization, e.g., university, research institute, industry, or government. The control variables include: the duration of the collaborative project, the geographical distance between the collaborators, and the availability of information technology to the members of the project consortium.

\section{Method}

\section{Approaches and Operationalization}

Central to our conceptual framework is the MOA framework of which the MOA components are interrelated and distinct concepts. We apply a Structural Equation Modeling (SEM) with reflective ${ }^{3}$ measurements to match the theoretical framework's interrelated explanatory variables. SEM is useful for disentangling the effects of the theoretical constructs and/or confounding variables from the effects of the organizational/relationship types, which all contribute to variations in the extent of the inter-organizational knowledge collaboration. SEM tests a set of relationships between explanatory variables, simultaneous with the effects of control variables, exerting influence on the dependent variable. This is done by examining the variance/covariance matrix of all variables simultaneously. Moreover, in confirmatory factor analysis (CFA), as a measurement model for testing the reliability and validity of latent constructs prior to SEM, each measurement item has to load on one and only one

\footnotetext{
${ }^{3}$ As opposed to formative measurements
} 
construct. This expression of CFA, and the consecutive structural model in SEM, fits another MOA framework assertion which mandates distinct conceptual constructs. Furthermore, the distinctness of the constructs (representing each concept) becomes testable by SEM methodology through the discriminant validity test.

Table 1 shows the operationalization of the conceptual framework that is used in the empirical analysis. The list includes the dependent variable (i.e., inter-organizational knowledge collaboration, IKC), a set of control variables (i.e., project duration, geographical distance, and IT availability), the MOA theoretical framework concepts (i.e., motivation, opportunity, and ability), and two sets of dummy variables (i.e., organization type and inter-organizational relationship type). We adapted the dependent variable to the inter-organizational context using Davenport and Prusak (1998) and Muthusamy and White (2005). We adopted the control variables from Gertler and Levitte (2005), Sher and Lee (2004), and Zaheer and McEvily (1999). The operationalization of the three MOA constructs is guided by Jarvenpaa et al. (1998), Muthusamy and White (2005), and Song and Parry (1993).

\section{Dummy Variable Approach}

Organizational/inter-organizational relationship types are included as exogenous observed dummy variables. Dummy variables are useful for modeling variables that are not conventionally measured on a numerical scale such as organizational type and interorganizational relationship type. Including all categories of a variable in a regression equation introduces singularity in the moment matrix. The moment matrix singularity is

Table 1 Operationalization

\begin{tabular}{|c|c|}
\hline Construct & Items \\
\hline IKC (dependent variable) & $\begin{array}{l}\text { IKC1 - extent of involvement in group discussions } \\
\text { IKC2 - development of new ideas/skills due to collaboration } \\
\text { IKC3 - extent of learning to exchange ideas/skills }\end{array}$ \\
\hline Controls & $\begin{array}{l}z \text { Duration - collaborative project's duration } \\
z \text { Distance - geographical distance between the collaborators } \\
z \text { IT - extent of available IT systems relevant to knowledge collaboration }\end{array}$ \\
\hline Motivation & $\begin{array}{l}\text { M1 - availability of incentives to work on ideas } \\
\text { M2 - existence of encouragement to keep trying } \\
\text { M3 - formal promotion of knowledge collaboration }\end{array}$ \\
\hline Opportunity & $\begin{array}{l}\mathrm{O} 1 \text { - extent of additional (to contracted) spent time } \\
\mathrm{O} 2 \text { - extent of additional (to contracted) spent effort }\end{array}$ \\
\hline Ability & $\begin{array}{l}\text { A1 - extent of organizational capability } \\
\text { A2 - extent of specialized capability } \\
\text { A3 - extent of success at execution of organizational plans }\end{array}$ \\
\hline Organization type & $\begin{array}{l}\text {-Dummy variables for business (B), university }(\mathrm{U}) \text {, research institute }(\mathrm{R}) \text {, } \\
\text { and administrative }(\mathrm{A})\end{array}$ \\
\hline $\begin{array}{l}\text { Inter-organizational } \\
\text { relationship type }\end{array}$ & $\begin{array}{l}\text {-Dummy variables for business and business }(\mathrm{B} \& \mathrm{~B}) \text {, university and } \\
\text { university (U\&U), research institute and research institute (R\&R), } \\
\text { administrative and administrative (A\&A), and six inter-type } \\
\text { relationships: } B \& R, U \& B, U \& R, A \& B, A \& U \text {, and A\&R }\end{array}$ \\
\hline
\end{tabular}


due to the perfect linear multiple correlation among the categories. "Constraining the constant to zero" or "omitting one category in regression equations as a baseline" are two alternative solutions to this issue (Suits 1957). Both solutions yield identical results (Suits 1957). In this research, we omit one category as a baseline. However, the outcome of tests of comparative effects is dependent on the choices made about which group is omitted and used as the baseline (Hayes and Preacher 2014). Therefore, we investigate three models, with three different baselines for each hypothesis, to provide a more complete picture.

\section{Data}

Empirical inter-organizational knowledge collaboration studies often use quantitative datasets on patents, licensing, and co-authoring (e.g., Acs et al. 2002; Anselin et al. 1997; Coenen et al. 2004; Fischer and Varga 2003; Jaffe et al. 1992). Clearly, patent data excludes forms of collaboration that do not result in patents or types of innovation for which patents are not important. Although patents are a relevant measure of application-oriented collaboration, not all of such collaborations lead to a patent (Acs et al. 2002). The same holds for co-authorship and licensing. Transfer-based interactions between universities and businesses (i.e., use of codified knowledge of research papers, patents or prototypes) play a moderate role, providing a need for studying "bench-level" interactions in inter-organizational knowledge collaboration networks (Perkmann and Walsh 2007). Studies on knowledge collaboration between universities mainly focus on co-authorship and citation counts of scientific papers or patents. This paper complements these studies by investigating the university's roles from an application-oriented bench-level perspective (Godin and Gingras 2000, p.277).

An example of the "bench-level" knowledge collaboration of diverse organizational types is the Framework Programmes for Research and Technological Development (FPs). FPs are an example of global inter-organizational knowledge collaboration that deal with the grand challenges of the society. More than $€ 112$ billion was spent on FP1 to FP7 until 2013 and an estimated additional $€ 80$ billion will be spent under the Horizon 2020 scheme. The Community Research and Development Information Service (CORDIS) website (available at http://cordis.europa.eu) provides detailed information on publically funded projects under the FPs. CORDIS dataset is relevant to this research since FPs represent collaborations of several organizational types and diverse inter-organizational knowledge collaboration relationships, and allows us to investigate these "bench-level" knowledge collaborations. Moreover, providing a cross-border set of observations enhances the generalizability. Also, homogeneous institutional norms of FPs across all project consortia, exerted by the EC and peer researchers, facilitate the interpretations of empirical results by avoiding the impact of outliers. We use the inter-organizational knowledge collaborations in FP7-Energy as a random sub-sample.

The FP7-Energy consists of 367 project entries (retrieved from CORDIS website before 12 March 2015). After refining the data using cloud computational "Google Refine" software, we identified 2262 organizations that collaborated in teams (i.e.,

\footnotetext{
${ }^{4}$ For instance, an organization which is not a business, a university, nor a research institute is determinatively an administrative organization according to this paper's all-inclusive categorization of organization types.
} 
more than one participant per project). Each organization can participate in more than one project consortium (i.e., multiple participations per participant). The number of participations was 3910. The target group consists of key staff as these are directly involved in the projects, are informed about the operational team's performance, and attend project steering committee meetings. Key staff can represent their organization in various consortia.

We acquired the email addresses of 2050 key staff, and asked them to participate in an online survey. After 2 weeks, we sent reminders to non-respondents. A total of 634 $(31 \%)$ key staff started filling in the survey from which we obtained 479 completed forms. We excluded five responses due to inconsistencies between their input and CORDIS data. We analyzed a total of 474 responses related to the respondents' own organization, a singled-out anonymous partner organization, and their collaborative project consortium. We used the respondents' organization type to investigate organizational type differences, and used the combination of the organizational type of the respondents and their singled-out anonymous partner to investigate inter-organizational relationship type differences.

To examine whether a response bias exists, we employed a two-independent sample $t$ test to test for differences between the respondents and an equally sized group of randomly selected non-respondents regarding: (1) project duration, (2) project cost, and (3) the amount of EU funding. We found no significant differences at the $90 \%$ confidence interval. ${ }^{5}$

By design, our research is based on a single-informant survey, which means that the variables are measured as self-reported items. In order to test whether this survey design influences the variance, we performed four statistical tests to test common method bias (CMB): Harman's single-factor test, principal component analysis (PCA), CFA with a constrained constant latent variable, and constraint-free CFA. The results ${ }^{6}$ of all these tests suggest that common method variance is unlikely to confound the interpretations of our research results.

\section{Results}

Table 2 lists data related to organization and inter-organizational relationship types. Associations, government organizations, and not-for-profit organizations were pooled together and labeled as administrative (A). Business organizations (B) are the most frequent organizational type in this FP7-Energy survey. Administrative organizations are the least frequent. Therefore, collaborative relationships involving administrative organizations are also the least frequent relationship types. Business and research

\footnotetext{
${ }^{5}$ The tests statistic values were $t(861)=0.21, p=0.83$ (project duration); $t(872)=-1.58, p=0.12$ (project cost), $t(872)=-1.35, p=0.18$ (amount of EU funding).

${ }^{6}$ The constrained single factor did not account for the majority of the variance $(33 \%<50 \%)$. Freeing the single-factor constraint, 11 items (items in Table 2 excluding the controls) loaded on more than one factor. Four factors emerged using the varimax rotation in the principal component analysis corresponding to the first four factors. The CFA measurement model with a constrained constant latent variable determining all items did not converge. Paths of constraint-free latent factor to the measurement items in CFA were not significant at a $90 \%$ confidence interval.
} 
institute (B\&R), university and research institute (U\&R), plus business and business $(B \& B)$ relationships were the top three most frequent relationship types. ${ }^{7}$

We tested the constructs (i.e., operationalized concepts) for reliability. The results show values greater than 0.75 on Cronbach's $\alpha$ measure (see Table 3 ). Widely accepted model-to-data fit indices for CFA are chi-squared per degrees of freedom $\left(\chi^{2} / \mathrm{df}\right)$, root mean square error of approximation (RMSEA) and its corresponding $p$ of close fit $-p$ value of one-sided test of the null hypothesis that the RMSEA equals $0.05-$ ( $p$ close), Comparative Fit Index (CFI) and Tucker-Lewis Index (TLI), and standardized root mean square residual (SRMR). CFA confirmed the measurement model by meeting all these fit criteria with conservative cutoff points: $\chi^{2} / \mathrm{df}$ below 3 (1.696, the lower the better), RMSEA below 0.05 ( 0.038 , the lower the better) with insignificant $p$ close at 0.05 level (0.882, the higher the better), CFI and TLI above 0.95 ( 0.988 and 0.983 , respectively, the higher the better), and SRMR below 0.08 ( 0.032 , the lower the better). We also tested for convergent validity. All average variances extracted (AVE) were above 0.5 , assuring construct validity. The discriminant validity was established by exhibiting that all correlations between the constructs were smaller than the squared root of the corresponding AVEs. Thus, indicators of each latent construct share more variance within themselves than they do with other variables.

Table 3 shows the descriptive statistics. IKC and MOA constructs are centered, i.e., data points are linearly shifted to a mean of zero. Additionally, control variables (starting with " $z$ " in Tables 5 and 6) are standardized as $z$-scores, i.e., have zero mean and unit variance. The average duration of FP7-Energy projects was 929.5 days (i.e., 31 months), with 29 days as standard error. The average travel time between the respondents and their partner organization was about four and half hours, with less than 6 minutes as standard error. The average extent of availability of IT systems was 2.8 , with 0.07 standard error.

In Table 4, the MOA constructs and the dependent variable IKC have different means in each category of organizational type. Except for motivation, the mean differences are significant (F-test in ANOVA). This justifies the inclusion of MOA to explain the IKC variation. Thus, to estimate the exact impact of organizational type on IKC, we disentangled the IKC variations due to MOA.

We estimated the impact of organizational type on the extent of knowledge collaboration using dummy variables. The baseline for comparison by a dummy variable can be any of the major organizational types. The coefficients of the other organizational types in each model are a measure of the impact of those types compared to the baseline. We assigned three organizational types, i.e., business, university, and research institutes, as the baselines in three models $\left(\operatorname{Model}_{1}-\mathrm{Model}_{3}\right)$. As administrative organizations constitute the smallest group in the observations, they are not taken as the baseline. We applied the same dummy variable approach to measure the comparative impact of the remaining nine relationship types with $B \& B, U \& U$, and $R \& R$ as baselines in three models $\left(\right.$ Model $_{4}-$ Model $\left._{6}\right)$.

Table 5 reports the results of comparative organizational type impacts on IKC in three models: business, university, and research institute, respectively, in $\mathrm{Model}_{1}$, $\mathrm{Model}_{2}$, and Model $_{3}$. $\beta$ s are the standardized regression coefficients which measure whether each

\footnotetext{
${ }^{7}$ Sideridis et al. (2014), investigating the appropriate sample size of SEM methodology, found 50 to be a satisfying sample size for a four-latent construct model. Our sample of 472 respondents complies with those sample size considerations.
} 
Table 2 Organizational and inter-organizational relationship types

\begin{tabular}{lcclrr}
\hline Organizational type (respondent) & Frequency & Percent & $\begin{array}{l}\text { Inter-organizational } \\
\text { relationship }\end{array}$ & Frequency & Percent \\
\hline Business (B) & 175 & 37.08 & B\&B & 65 & 13.77 \\
University (U) & 111 & 23.52 & U\&U & 46 & 9.75 \\
Research institute (R) & 132 & 27.97 & R\&R & 57 & 12.08 \\
Administrative (A) & 54 & 11.44 & A\&A & 13 & 2.75 \\
& & & B\&R & 59 & 73 \\
(Singled-out partner) & & & U\&B & 22 & 12.50 \\
Business (B) & 144 & 30.51 & U\&R & 18 & 15.47 \\
University (U) & 132 & 27.97 & A\&B & 11 & 3.81 \\
Research institute (R) & 173 & 36.65 & A\&U & A\&R & 2.33 \\
Administrative (A) & 23 & 4.87 & & &
\end{tabular}

organization type exhibits more or less IKC compared to the baseline. For example, a significant negative $\beta$ for business $(\beta=-0.26, p<0.01)$ when university is the baseline $\left(\mathrm{Model}_{2}\right)$ means that businesses exhibit significantly $26 \%$ less IKC than universities. Figure 1 is the path diagram of Model $_{2}$.

Model $_{1}$ portrays $23 \%$ more IKC for universities $(\beta=0.23, p<0.01)$ compared to businesses (i.e., the baseline). Based on the negative coefficients for business, research institute, and administrative organization types in $\mathrm{Model}_{2}$, and the significantly positive coefficient of university compared to business in Model $_{1}$, we can conclude that universities collaborate more extensively compared to the other organizational types. Hypothesis 1 cannot be rejected. THm propositions hold while there is no evidence for the assertions of the Mode 2 model.

Moreover, the MOA components have a significant positive impact on IKC in all models. As expected, the more motivation, opportunity, and ability of an organization, the higher the extent of knowledge collaboration. The control variables, project duration, geographical distance, and IT systems relevant to knowledge collaboration all significantly influence the extent of knowledge collaboration. As expected, project duration and geographical distance have a negative impact, whereas IT has a positive role in facilitating

Table 3 Descriptive statistics

\begin{tabular}{llllllr}
\hline & & $N$ & Cronbach's $\alpha$ & AVE & Mean & Std. error \\
\hline Constructs: & IKC & 472 & 0.78 & 0.57 & 0.0026 & 0.0286 \\
& Motivation & 472 & 0.85 & 0.67 & 0.0012 & 0.0528 \\
& Opportunity & 472 & 0.91 & 0.83 & 0.0017 & 0.0471 \\
& Ability & 472 & 0.80 & 0.59 & 0.0010 & 0.0296 \\
Cnstandardized & Duration (days) & 472 & & & 928.7542 & 28.9955 \\
& Distance (7-point Likert scale 0-6) & 472 & & & $2.8369^{\mathrm{a}}$ & 0.0615 \\
& IT availability (7-point Likert scale 0-6) & 472 & & & 2.8242 & 0.0722 \\
\hline
\end{tabular}

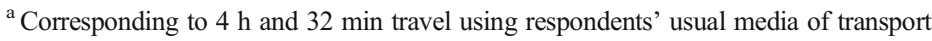


Table 4 Constructs' means as per organizational type

\begin{tabular}{llllll}
\hline & $\begin{array}{l}\text { Business } \\
\text { Mean } \\
\text { (standard error) }\end{array}$ & $\begin{array}{l}\text { University } \\
\text { Mean } \\
\text { (standard error) }\end{array}$ & $\begin{array}{l}\text { Research institute } \\
\text { Mean } \\
\text { (standard error) }\end{array}$ & $\begin{array}{l}\text { Administrative } \\
\text { Mean } \\
\text { (standard error) }\end{array}$ & $\begin{array}{l}\text { ANOVA } \\
\mathrm{F}^{\mathrm{p} \text { value }}\end{array}$ \\
\hline IKC & -0.15 & 0.21 & 0.05 & -0.06 & $8.32 * * *$ \\
Motivation & $(0.05)$ & $(0.06)$ & $(0.05)$ & $(0.08)$ & $0.50^{0.69}$ \\
& -0.04 & 0.06 & 0.07 & -0.12 & $(0.16)$ \\
Opportunity & $-0.08)$ & $(0.13)$ & $(0.09)$ & -0.03 & $2.84 * *$ \\
Ability & $(0.08)$ & 0.10 & 0.14 & $(0.13)$ & $7.37 * * *$ \\
& -0.13 & $(0.10)$ & $(0.08)$ & -0.18 & $(0.09)$ \\
\hline
\end{tabular}

$p \leq 0.10 ; * * p \leq 0.05 ; * * * p \leq 0.01$

IKC. The SEM structural model fits the data by meeting conservative cutoff points (as of CFA fit criteria) on all fit indices. These indices are reported in the last row of Table 5.

Figure 1, the path diagram of $\mathrm{Model}_{2}$ in Table 5, reports additional results. Latent constructs IKC, motivation, opportunity, and ability are presented by eclipses. Means of observed endogenous variables (measurement items) are reportedat the bottom right corner of each rectangle. By reflective measurement, the latent variables load on measurement items. The loadings are presented by unidirectional straight arrows and are reported next to each unidirectional arrow. Covariance of interrelated explanatory variables are shown in curved bidirectional arrows and are reported next to each curved arrow. Causal influence of the theoretical framework constructs, control variables, and dummy variables are shown in straight directional arrows towards the latent endogenous variable IKC. All errors of variance of endogenous variables are isolated as latent exogenous variables in circles and are reported next to each circle.

Table 6 reports the results of SEM analysis with a dummy variable approach for different inter-organizational relationship types. Depicted by significant positive coefficients of $\mathrm{Model}_{4}$ in Table 6 , the B\&B relationship shows a significantly less extensive knowledge collaboration compared to $\mathrm{U} \& \mathrm{U}(\beta=0.23, p<0.01), \mathrm{R} \& \mathrm{R}(\beta=0.11$, $p<0.10)$, and $\mathrm{U} \& \mathrm{R}(\beta=0.14, p<0.05)$ relationship types. Depicted by significant negative coefficients of $\mathrm{Model}_{5}$ in Table 6 , the U\&U relationship shows a significantly more extensive knowledge collaboration compared to $\mathrm{B} \& \mathrm{~B}(\beta=-0.26, p<0.01)$, $\operatorname{R} \& \mathrm{R}(\beta=-0.14, p<0.05), \mathrm{A} \& \mathrm{~A}(\beta=-0.16, p<0.01), \mathrm{B} \& \mathrm{R}(\beta=-0.28, p<0.01)$, $\mathrm{U} \& \mathrm{~B}(\beta=-0.18, p<0.01), \mathrm{U} \& \mathrm{R}(\beta=-0.14, p<0.05)$, and $\mathrm{A} \& \mathrm{~B}(\beta=-0.10$, $p<0.10)$ relationship types. Taking into account the theoretical constructs and contextual confounding variables simultaneously, the U\&U inter-organizational relationship type shows a significantly more extensive knowledge collaboration compared to the B\&B relationship type. Contrary to the claims of the Mode 2 model, all evidence is in line with the propositions of the Triple Helix model in inter-organizational knowledge collaborations. Hypothesis 2 cannot be rejected.

The impacts of motivation, opportunity, ability, project duration, geographical distance, and the availability of IT systems kept their significance and sign in all six models. Based on all models, conform to our expectations, we can conclude that the higher the MOA, the higher the IKC. The longer the duration of a project, the less the 
Table 5 Results of SEM regressions of organizational types

\begin{tabular}{|c|c|c|c|c|}
\hline & Model & $\begin{array}{l}\text { SEM dummy-var. } \\
\text { Org. type } \\
\text { Baseline business }_{\text {Model }_{1}}\end{array}$ & $\begin{array}{l}\text { SEM dummy-var. } \\
\text { Org. type } \\
\text { Baseline university } \\
\text { Model }_{2}\end{array}$ & $\begin{array}{l}\text { SEM dummy-var. } \\
\text { Org. type } \\
\text { Baseline research ins. } \\
\text { Model }_{3}\end{array}$ \\
\hline Explanatory variable & & $\begin{array}{l}\beta \\
\text { (S.E.) }\end{array}$ & $\begin{array}{l}\beta \\
\text { (S.E.) }\end{array}$ & $\begin{array}{l}\beta \\
\text { (S.E.) }\end{array}$ \\
\hline \multirow[t]{3}{*}{ Controls: } & $z$ Duration & $\begin{array}{l}-0.10^{* * *} \\
(0.05)\end{array}$ & $\begin{array}{l}-0.10^{* * *} \\
(0.05)\end{array}$ & $\begin{array}{l}-0.10^{* *} \\
(0.05)\end{array}$ \\
\hline & $z$ Distance & $\begin{array}{l}-0.10^{* * *} \\
(0.05)\end{array}$ & $\begin{array}{l}-0.10^{* * *} \\
(0.05)\end{array}$ & $\begin{array}{l}-0.10 * * \\
(0.05)\end{array}$ \\
\hline & $z \mathrm{IT}$ & $\begin{array}{l}0.22 * * * \\
(0.05)\end{array}$ & $\begin{array}{l}0.22 * * * \\
(0.05)\end{array}$ & $\begin{array}{l}0.22 * * * \\
(0.05)\end{array}$ \\
\hline \multirow[t]{3}{*}{ Theoretical framework: } & Motivation & $\begin{array}{l}0.12 * * \\
(0.05)\end{array}$ & $\begin{array}{l}0.12 * * \\
(0.05)\end{array}$ & $\begin{array}{l}0.12 * * \\
(0.05)\end{array}$ \\
\hline & Opportunity & $\begin{array}{l}0.10 * \\
(0.05)\end{array}$ & $\begin{array}{l}0.10^{*} \\
(0.05)\end{array}$ & $\begin{array}{l}0.10^{*} \\
(0.05)\end{array}$ \\
\hline & Ability & $\begin{array}{l}0.27 * * * \\
(0.06)\end{array}$ & $\begin{array}{l}0.27 * * * \\
(0.06)\end{array}$ & $\begin{array}{l}0.27 * * * \\
(0.06)\end{array}$ \\
\hline \multirow[t]{5}{*}{ Organizational type: } & Business & Baseline & $\begin{array}{l}-0.26^{* * *} \\
(0.06)\end{array}$ & $\begin{array}{l}-0.09 \\
(0.06)\end{array}$ \\
\hline & University & $\begin{array}{l}0.23 * * * \\
(0.05)\end{array}$ & Baseline & $\begin{array}{l}0.15 * * * \\
(0.05)\end{array}$ \\
\hline & Research Ins. & $\begin{array}{l}0.09 \\
(0.05)\end{array}$ & $\begin{array}{l}-0.16^{* * *} \\
(0.06)\end{array}$ & Baseline \\
\hline & Administrative & $\begin{array}{l}0.06 \\
(0.05)\end{array}$ & $\begin{array}{l}-0.11 * * \\
(0.05)\end{array}$ & $\begin{array}{l}0.00 \\
(0.05)\end{array}$ \\
\hline & SRMR & 0.057 & 0.060 & 0.059 \\
\hline
\end{tabular}

Dependent variable: extent of the inter-organizational knowledge collaboration (IKC)

$\beta \mathrm{s}$ are standardized coefficients. (S.E.) is standard error

$N=472$

Model fit indices: $\log$ likelihood $=-9493.997 ; \chi^{2} / \mathrm{df}=1.88 ; \operatorname{RMSEA}[p$ close $]=0.043[0.875] ; \mathrm{CFI}=0.964$; $\mathrm{TLI}=0.955$

$* p \leq 0.10 ; * * p \leq 0.05 ; * * * p \leq 0.01$

extent of the knowledge collaboration, which can be attributed to coordination issues in longer projects. This can also be caused by the lack of a sense of urgency in longer projects. Geographical distance between the collaborators has a significant negative impact on the extent of the knowledge collaboration. The availability of the IT systems has a significant positive impact on the extent of the knowledge collaboration. Fit indices of Model $_{4}-$ Model $_{6}$ can be found in the last row of Table 6 .

\section{Limitations and Implications}

The focus of this paper was on EU level FP funding. National programs or non-EU funding schemes may have different dynamics, and would also be worth studying. FP 


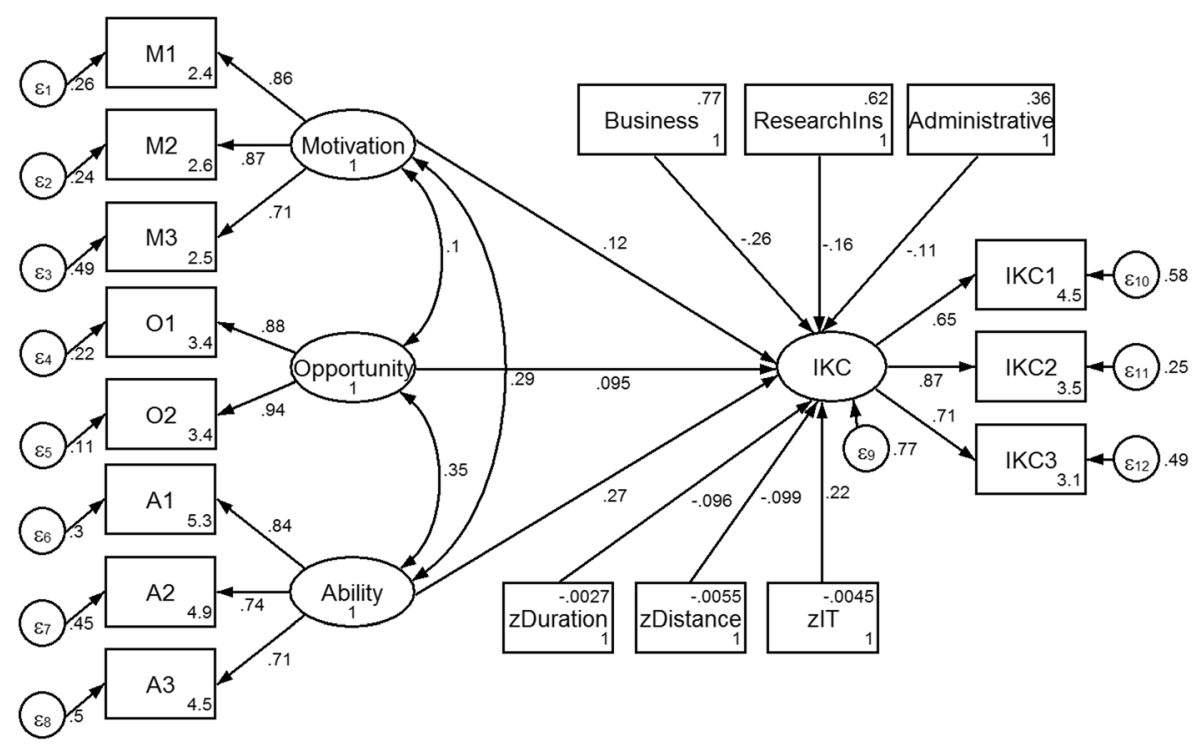

Fig. 1 Path diagram of $\mathrm{Model}_{2}$

projects are funded after being peer-reviewed in accordance with a common review protocol; thus, all projects showed above-standard performance. Since rejected proposals and not-applied proposals are omitted by this selection method, the input data might exhibit pre-selection sample-bias. Consequently, the implications of the results specially hold for above-standard performing organizations. For generalization, future work could address these concerns by including a priori rejected or a posteriori failed inter-organizational knowledge collaboration project. Moreover, universities and businesses were categorized uniformly. A more comprehensive categorization of, e.g., technical/non-technical university or public/private business, may enhance the level of detail.

The findings nevertheless conform to the Horizon 2020 context and imply that universities' salient role can be strengthened in order to facilitate inter-organizational knowledge collaboration networks. More specifically, publically funded consortia can be composed taking into account that universities are more conducive and hence more effective in inter-organizational knowledge collaboration networks than other organizational types, specifically compared to for-profit business organizations. Replacing universities with businesses in a consortium is likely to reduce the extent of knowledge collaboration in the consortium.

We need to take into account the fact that business organizations are not conducive to inter-organizational knowledge collaboration. These organizations benefit from keeping knowledge private and proprietary. We cannot expect businesses to broadcast knowledge to their rivals. Business organizations that do not have an extensive relationship with universities need to reconsider their partner portfolio and extend the knowledge collaboration of their network by connecting to more universities. Stereotyping university knowledge as "knowledge in books" can change to a recognition of academic knowledge as a "practical" potential source of sustained competitive advantage. 
Table 6 Results of SEM regressions of inter-organizational relationship types

\begin{tabular}{|c|c|c|c|c|}
\hline & Model & $\begin{array}{l}\text { SEM dummy-var. } \\
\text { Relationship type } \\
\text { Baseline B\&B }_{\text {Model }_{4}}\end{array}$ & $\begin{array}{l}\text { SEM dummy-var. } \\
\text { Relationship type } \\
\text { Baseline U\&U }_{\text {Model }_{5}}\end{array}$ & $\begin{array}{l}\text { SEM dummy-var. } \\
\text { Relationship type } \\
\text { Baseline R\&R }_{\text {Model }_{6}}\end{array}$ \\
\hline Explanatory variable & & $\begin{array}{l}\beta \\
\text { (S.E.) }\end{array}$ & $\begin{array}{l}\beta \\
\text { (S.E.) }\end{array}$ & $\begin{array}{l}\beta \\
\text { (S.E.) }\end{array}$ \\
\hline \multirow[t]{3}{*}{ Controls: } & $z$ Project duration & $\begin{array}{l}-0.09 * * \\
(0.05)\end{array}$ & $\begin{array}{l}-0.09^{* *} \\
(0.05)\end{array}$ & $\begin{array}{l}-0.09 * * \\
(0.05)\end{array}$ \\
\hline & $z$ Distance & $\begin{array}{l}-0.10^{* *} \\
(0.05)\end{array}$ & $\begin{array}{l}-0.10^{* *} \\
(0.05)\end{array}$ & $\begin{array}{l}-0.10 * * \\
(0.05)\end{array}$ \\
\hline & zIT availability & $\begin{array}{l}0.20 * * * \\
(0.05)\end{array}$ & $\begin{array}{l}0.20 * * * \\
(0.05)\end{array}$ & $\begin{array}{l}0.20 * * * \\
(0.05)\end{array}$ \\
\hline \multirow[t]{3}{*}{ Theoretical framework: } & Motivation & $\begin{array}{l}0.12 * * \\
(0.05)\end{array}$ & $\begin{array}{l}0.12^{* *} \\
(0.05)\end{array}$ & $\begin{array}{l}0.12 * * \\
(0.05)\end{array}$ \\
\hline & Opportunity & $\begin{array}{l}0.09 * \\
(0.05)\end{array}$ & $\begin{array}{l}0.09 * \\
(0.05)\end{array}$ & $\begin{array}{l}0.09 * \\
(0.05)\end{array}$ \\
\hline & Ability & $\begin{array}{l}0.27 * * * \\
(0.06)\end{array}$ & $\begin{array}{l}0.27 * * * \\
(0.06)\end{array}$ & $\begin{array}{l}0.27 * * * \\
(0.06)\end{array}$ \\
\hline \multirow[t]{10}{*}{ Relationship type: } & $\mathrm{B} \& \mathrm{~B}$ & Baseline & $\begin{array}{l}-0.26^{* * * *} \\
(0.07)\end{array}$ & $\begin{array}{l}-0.12 * \\
(0.06)\end{array}$ \\
\hline & $\mathrm{U} \& \mathrm{U}$ & $\begin{array}{l}0.23 * * * \\
(0.06)\end{array}$ & Baseline & $\begin{array}{l}0.13^{* *} \\
(0.06)\end{array}$ \\
\hline & $\mathrm{R} \& \mathrm{R}$ & $\begin{array}{l}0.11 * \\
(0.06)\end{array}$ & $\begin{array}{l}-0.14^{* * *} \\
(0.06)\end{array}$ & Baseline \\
\hline & A\&A & $\begin{array}{l}-0.03 \\
(0.05)\end{array}$ & $\begin{array}{l}-0.16^{* * * *} \\
(0.05)\end{array}$ & $\begin{array}{l}-0.09 * \\
(0.05)\end{array}$ \\
\hline & $\mathrm{B} \& \mathrm{R}$ & $\begin{array}{l}0.04 \\
(0.07)\end{array}$ & $\begin{array}{l}-0.28^{* * * *} \\
(0.07)\end{array}$ & $\begin{array}{l}-0.11 \\
(0.07)\end{array}$ \\
\hline & $\mathrm{U} \& \mathrm{~B}$ & $\begin{array}{l}0.07 \\
(0.06)\end{array}$ & $\begin{array}{l}-0.18 \text { *** } \\
(0.06)\end{array}$ & $\begin{array}{l}-0.04 \\
(0.06)\end{array}$ \\
\hline & $\mathrm{U} \& \mathrm{R}$ & $\begin{array}{l}0.14 * * \\
(0.06)\end{array}$ & $\begin{array}{l}-0.14^{* *} \\
(0.07)\end{array}$ & $\begin{array}{l}0.01 \\
(0.06)\end{array}$ \\
\hline & $\mathrm{A} \& \mathrm{~B}$ & $\begin{array}{l}0.06 \\
(0.05)\end{array}$ & $\begin{array}{l}-0.10 * \\
(0.05)\end{array}$ & $\begin{array}{l}-0.01 \\
(0.05)\end{array}$ \\
\hline & $\mathrm{A} \& \mathrm{U}$ & $\begin{array}{l}0.07 \\
(0.05)\end{array}$ & $\begin{array}{l}-0.07 \\
(0.05)\end{array}$ & $\begin{array}{l}0.01 \\
(0.05)\end{array}$ \\
\hline & $A \& R$ & $\begin{array}{l}0.08 \\
(0.05)\end{array}$ & $\begin{array}{l}-0.03 \\
(0.05)\end{array}$ & $\begin{array}{l}0.03 \\
(0.05)\end{array}$ \\
\hline SRMR & & 0.045 & 0.046 & 0.046 \\
\hline
\end{tabular}

Dependent variable: extent of the inter-organizational knowledge collaboration (IKC)

$\beta$ s are standardized coefficients. (S.E.) is standard error

$N=472$

Model fit indices: Log likelihood $=-8863.2597 ; \chi^{2} / \mathrm{df}=1.51 ; \operatorname{RMSEA}[p$ close $]=0.033$ [1.000]; CFI $=$ 0.966 ; $\mathrm{TLI}=0.960$

$* p \leq 0.10 ; * * p \leq 0.05 ; * * * p \leq 0.01$ 
Universities have the main responsibility and power in shaping regional economic capability and competitiveness in the knowledge-based economy. Academia can become aware of this power and use it to conduct and extend inter-organizational knowledge collaborations. Stereotyping academics who collaborate with businesses as turncoats can change to a recognition of business-oriented collaboration as a source of insight for theory development and/or the validation of research results as well as an accomplishment of the public mission.

Administrative structures, specifically the European Commission, can use these findings in their perspective on diverse organization types in inter-organizational knowledge collaboration for resource allocation and division of labor. Administrative structures might instill the findings of this research in their new policies on the structure of the to-be-funded consortia, for instance, in Horizon 2020. The message to the policymakers is to involve academic organizations in groups of more than one per consortia to enable between-university knowledge collaboration.

Finally, collaborating organizations can address the need for shorter, more easily manageable projects powered by direct contacts by decreasing the distance between their sites/partners and by providing collaboration-related IT systems to their operational team.

\section{Conclusion}

By studying the collaborative knowledge exploration and exploitation in interorganizational knowledge networks of FP7-Energy, we empirically examined the impact of organization type on the extent of inter-organizational knowledge collaboration at the organizational and at the inter-organizational levels. Empirical evidence depicted the central role of universities in innovation systems by studying bench-level knowledge interactions rather than examining scientific papers or patent count/citations. The results provide empirical support for the predictions of the Triple Helix model (Leydesdorff and Etzkowitz 1998) and show no evidence for the claims of the Mode 2 model (Gibbons et al. 1994). At the organizational level, our findings show that universities are the organizational type with the most extensive knowledge collaboration with regard to the extent of their involvement in group discussions, in the development of new ideas/skills, and in the extent of learning to exchange ideas/ skills (as manifestations in a reflective construction).

At an inter-organizational relationship level, our results show that a U\&U knowledge collaboration relationship is the most extensive compared to other major relationship types. B\&B relationships are less extensive than U\&U. In this paper, being open or closed to external organizations is ascribed to the stance of an organization with regard to the public or private dimension of knowledge: whether an organization aims to "safeguard" its knowledge and keep it proprietary and private, or aims to publically "disseminate" as much knowledge as possible. The differing extents of interorganizational knowledge collaborations can be attributed to the different and often opposing organizational agendas of businesses and universities. These findings are most relevant for resource allocation of publically funded projects (e.g., Horizon 2020) in which underinvestment in and exclusion of the role of universities can likely negatively impact the extent of inter-organizational knowledge collaboration. 
Policymakers might not only involve academic organizations, but also include groups of more than one university per consortium to enable between-university knowledge collaboration to boost collaborative knowledge exploration and exploitation of the consortia.

Open Access This article is distributed under the terms of the Creative Commons Attribution 4.0 International License (http://creativecommons.org/licenses/by/4.0/), which permits unrestricted use, distribution, and reproduction in any medium, provided you give appropriate credit to the original author(s) and the source, provide a link to the Creative Commons license, and indicate if changes were made.

\section{References}

Acs, Z. J., Anselin, L., \& Varga, A. (2002). Patents and innovation counts as measures of regional production of new knowledge. Research Policy, 31(7), 1069-1085.

Ajzen, I., \& Fishbein, M. (1970). The prediction of behavior from attitudinal and normative variables. Journal of Experimental Social Psychology, 6(4), 466-487.

Almeida, P., \& Kogut, B. (1999). Localization of knowledge and the mobility of engineers in regional networks. Management Science, 45(7), 905-917.

Alter, C., \& Hage, J. (1993). Organizations working together. Newbury Park: Sage Publications.

Anselin, L., Varga, A., \& Acs, Z. (1997). Local geographic spillovers between university research and high technology innovations. Journal of Urban Economics, 42(3), 422-448.

Argote, L., McEvily, B., \& Reagans, R. (2003). Managing knowledge in organizations: an integrative framework and review of emerging themes. Management Science, 49(4), 571-582.

Blumberg, M., \& Pringle, C. D. (1982). The missing opportunity in organizational research: some implications for a theory of work performance. Academy of Management Review, 7(4), 560-569.

Bock, G. W., Zmud, R. W., Kim, Y. G., \& Lee, J. N. (2005). Behavioral intention formation in knowledge sharing: examining the roles of extrinsic motivators, social-psychological forces, and organizational climate. MIS Quarterly, 29(1), 87-111.

Borgatti, S. P., \& Cross, R. (2003). A relational view of information seeking and learning in social networks. Management Science, 49(4), 432-445.

Brown, J. S., \& Duguid, P. (2001). Knowledge and organization: a social-practice perspective. Organization Science, 12(2), 198-213.

Caloghirou, Y., Tsakanikas, A., \& Vonortas, N. S. (2001). University-industry cooperation in the context of the European Framework Programmes. The Journal of Technology Transfer, 26(1-2), 153-161.

Carayannis, E. G., \& Campbell, D. F. (2011). Open innovation diplomacy and a 21st century fractal research, education and innovation (FREIE) ecosystem: building on the quadruple and quintuple helix innovation concepts and the "mode 3" knowledge production system. Journal of the Knowledge Economy, 2(3), 327-372.

Carayannis, E. G., Barth, T. D., \& Campbell, D. F. (2012). The Quintuple Helix innovation model: global warming as a challenge and driver for innovation. Journal of Innovation and Entrepreneurship, 1(1), 112.

Chesbrough, H. W. (2006). Open innovation: the new imperative for creating and profiting from technology. Harvard Business Press.

Clark, B. H., Abela, A. V., \& Ambler, T. (2005). Organizational motivation, opportunity and ability to measure marketing performance. Journal of Strategic Marketing, 13(4), 241-259.

Coenen, L., Moodysson, J., \& Asheim, B. T. (2004). Nodes, networks and proximities: on the knowledge dynamics of the Medicon Valley biotech cluster. European Planning Studies, 12(7), 1003-1018.

Cohen, W. M., \& Levinthal, D. A. (1990). Absorptive capacity: a new perspective on learning and innovation. Administrative Science Quarterly, 35(1), 128-152.

Cooke, P. N., Heidenreich, M., \& Braczyk, H. J. (2004). Regional innovation systems: the role of governance in a globalized world. Psychology Press.

Davenport, T. H., \& Prusak, L. (1998). Working knowledge: how organizations manage what they know. Harvard Business Press. 
Edquist, C. (2010). Systems of innovation perspectives and challenges. African Journal of Science, Technology, Innovation and Development, 2(3), $14-45$.

Etzkowitz, H. (1998). The norms of entrepreneurial science: cognitive effects of the new university-industry linkages. Research Policy, 27(8), 823-833.

Etzkowitz, H., \& Leydesdorff, L. (2000). The dynamics of innovation: from National Systems and "Mode 2" to a Triple Helix of university-industry-government relations. Research Policy, 29(2), 109-123.

Etzkowitz, H., \& Zhou, C. (2006). Triple Helix twins: innovation and sustainability. Science and Public Policy, 33(1), 77-83.

Etzkowitz, H., Webster, A., Gebhardt, C., \& Terra, B. R. C. (2000). The future of the university and the university of the future: evolution of ivory tower to entrepreneurial paradigm. Research Policy, 29(2), 313-330.

Feldman, M. P., \& Florida, R. (1994). The geographic sources of innovation: technological infrastructure and product innovation in the United States. Annals of the Association of American Geographers, 84(2), 210 229.

Fischer, M. M., \& Varga, A. (2003). Spatial knowledge spillovers and university research: evidence from Austria. The Annals of Regional Science, 37(2), 303-322.

Fishbein, M. (1967). Attitude and the prediction of behavior, in Martin Fishbein, (Ed.), Readings in attitude theory and measurement, New York: John Wiley and Sons, Inc.

Florida, R., \& Cohen, W. (1999). Engine or infrastructure? The university role in economic development. L. Branscomb, F. Kodama, \& R. Florida (Ed.) Industrializing Knowledge.589-610.

Foray, D. (2004). Economics of knowledge. MIT press.

Freeman, C. (1991). Networks of innovators: a synthesis of research issues. Research Policy, 20(5), 499-514.

Gertler, M. S., \& Levitte, Y. M. (2005). Local nodes in global networks: the geography of knowledge flows in biotechnology innovation. Industry and Innovation, 12(4), 487-507.

Gibbons, M., Limoges, C., Nowotny, H., Schwartzman, S., Scott, P., \& Trow, M. (1994). The new production of knowledge: the dynamics of science and research in contemporary societies. Sage.

Godin, B., \& Gingras, Y. (2000). The place of universities in the system of knowledge production. Research Policy, 29(2), 273-278.

Goh, S. C. (1998). Toward a learning organization: the strategic building blocks. SAM Advanced Management Journal, 63(2), 15.

Greenaway, D., \& Haynes, M. (2000). Funding universities for national and international competitiveness. School of Economics Policy Report, University of Nottingham.

Gunasekara, C. (2006). Reframing the role of universities in the development of regional innovation systems. The Journal of Technology Transfer, 31(1), 101-113.

Hagedoorn, J., Link, A. N., \& Vonortas, N. S. (2000). Research partnerships. Research Policy, 29(4), 567-586.

Hamel, G. (1991). Competition for competence and inter-partner learning within international strategic alliances. Strategic Management Journal, 12(4), 83-103.

Harlow, H. (2008). The effect of tacit knowledge on firm performance. Journal of Knowledge Management, 12(1), 148-163.

Hayes, A. F., \& Preacher, K. J. (2014). Statistical mediation analysis with a multicategorical independent variable. British Journal of Mathematical and Statistical Psychology, 67(3), 451-470.

Hewitt-Dundas, N. (2013). The role of proximity in university-business cooperation for innovation. The Journal of Technology Transfer, 38(2), 93-115.

Jaffe, A. B., Trajtenberg, M., \& Henderson, R. (1992). Geographic localization of knowledge spillovers as evidenced by patent citations (no. w3993). National Bureau of Economic Research.

Jarvenpaa, S. L., Knoll, K., \& Leidner, D. E. (1998). Is anybody out there? Antecedents of trust in global virtual teams. Journal of Management Information Systems, 14(4), 29-64.

Kelloway, E. K., \& Barling, J. (2000). Knowledge work as organizational behavior. International Journal of Management Reviews, 2(3), 287-304.

Lambert, R. (2003). Lambert review of business-university collaboration: final report. University of Illinois at Urbana-Champaign's Academy for Entrepreneurial Leadership Historical Research Reference in Entrepreneurship.

Leydesdorff, L., \& Etzkowitz, H. (1998). The Triple Helix as a model for innovation studies. Science and Public Policy, 25(3), 195-203.

Malmberg, A., \& Maskell, P. (2002). The elusive concept of localization economies: towards a knowledgebased theory of spatial clustering. Environment and Planning A, 34(3), 429-450.

Mansfield, E., \& Lee, J. Y. (1996). The modern university: contributor to industrial innovation and recipient of industrial R\&D support. Research Policy, 25(7), 1047-1058. 
Martin, B. R. (2003). The changing social contract for science and the evolution of the university. Science and innovation: rethinking the rationales for funding and governance (pp. 7-29). Cheltenham: Edward Elgar.

Mavi, R. K. (2014). Indicators of entrepreneurial university: fuzzy AHP and fuzzy TOPSIS approach. Journal of the Knowledge Economy, 5(2), 370-387.

Merton, R. K. (1973). The sociology of science: theoretical and empirical investigations. University of Chicago Press.

Milne, P. (2007). Motivation, incentives and organisational culture. Journal of Knowledge Management, 11(6), 28-38.

Mischel, W., \& Shoda, Y. (1995). A cognitive-affective system theory of personality: reconceptualizing situations, dispositions, dynamics, and invariance in personality structure. Psychological Review, 102(2), 246-268.

Muthusamy, S. K., \& White, M. A. (2005). Learning and knowledge transfer in strategic alliances: a social exchange view. Organization Studies, 26(3), 415-441.

Nelson, R. R. (2001). Observations on the post-Bayh-Dole rise of patenting at American universities. The Journal of Technology Transfer, 26(1), 13-19.

Olson, M. (1965). Logic of collective action public goods and the theory of groups Cambridge, Mass.

Partha, D., \& David, P. A. (1994). Toward a new economics of science. Research Policy, 23(5), 487-521.

Perkmann, M., \& Walsh, K. (2007). University-industry relationships and open innovation: towards a research agenda. International Journal of Management Reviews, 9(4), 259-280.

Powell, W., \& Grodal, S. (2005). Networks of innovators. In J. Fagerberg, D. Mowery, \& R. Nelson (Eds.), The Oxford Handbook of Innovation (pp. 56-85). Oxford: Oxford University Press.

Powell, W. W., Koput, K. W., \& Smith-Doerr, L. (1996). Interorganizational collaboration and the locus of innovation: networks of learning in biotechnology. Administrative Science Quarterly, 41(1), 116-145.

Schoonmaker, M. G., \& Carayannis, E. G. (2013). Mode 3: a proposed classification scheme for the knowledge economy and society. Journal of the Knowledge Economy, 4(4), 556-577.

Sher, P. J., \& Lee, V. C. (2004). Information technology as a facilitator for enhancing dynamic capabilities through knowledge management. Information Management, 41(8), 933-945.

Sideridis, G., Simos, P., Papanicolaou, A., \& Fletcher, J. (2014). Using structural equation modeling to assess functional connectivity in the brain power and sample size considerations. Educational and Psychological Measurement, 74(5), 733-758.

Song, X. M., \& Parry, M. E. (1993). R\&D marketing integration in Japanese high-technology firms: hypotheses and empirical evidence. Journal of the Academy of Marketing Science, 21(2), 125-133.

Srholec, M. (2014). Cooperation and innovative performance of firms: panel data evidence from the Czech Republic, Norway and the UK. Journal of the Knowledge Economy, 5(1), 133-155.

Stern, S. (2004). Do scientists pay to be scientists? Management Science, 50(6), 835-853.

Stiglitz, J. E., \& Wallsten, S. J. (1999). Public-private technology partnerships promises and pitfalls. American Behavioral Scientist, 43(1), 52-73.

Suits, D. B. (1957). Use of dummy variables in regression equations. Journal of the American Statistical Association, 52(280), 548-551.

Van Der Panne, G., \& Kleinknecht, A. (2005). Proximity and Knowledge Spillovers: evidence from New Product Announcements in the Netherlands. In World Bank-Cambridge-MIT Workshop on UniversityIndustry Linkages in Europe and North America, Cambridge, UK, September (Vol. 26).

Zaheer, A., \& McEvily, B. (1999). Bridging ties: a source of firm heterogeneity in competitive capabilities. Strategic Management Journal, 20(12), 1133.

Zahn, G. L. (1991). Face-to-face communication in an office setting the effects of position, proximity, and exposure. Communication Research, 18(6), 737-754. 